\title{
Social Impact of Virtual Communication on Nascent Society of Pakistan
}

\author{
Muhammad Nawaz Tunio ${ }^{1}$, Pir Irfan Shah Rashdi ${ }^{2}$, Qazi Muhammad \\ Moinuddin $\mathrm{Abro}^{3}$, Shabana Sartaj ${ }^{4}$, Shazia Parveen Tunio ${ }^{5}$ \\ ${ }^{I}$ Centre for Biosaline Agriculture (CBSA), Sindh Agriculture University, Tandojam \\ ${ }^{2 \& 3}$ Mehran University Institute of Arts, Science and Development (MUISTD), Mehran University of Engineering \\ and Technology, Jamshoro \\ ${ }^{4}$ Department of English, Faculty of Social Sciences, Sindh Agriculture University, Tandojam \\ ${ }^{5}$ Social Science Research Institute, PARC, Tandojam (Pakistan)
}

\begin{abstract}
Nascent society of Pakistan has potential towards the use of emerging technology for the social perspective, as social perspective of new technology has filled social gaps among the people living at distances. Besides filling social gaps, virtual communication has provided opportunity to find out new friends, people of different disciplines and to establish new social network and to extend social zone at local, national and international level. Through virtual communication, everybody is able to enjoy the taste of diversity which gives great social charm of life. This study focuses on the interest of the people of different disciplines towards the virtual communication.
\end{abstract}

Keywords: ICT, social network, communication.

\section{Introduction and background}

Communication with the help of electronic devices is a virtual communication. Information technology has integrated people and machines for the social cause. Computer has developed virtual communities where social interrelationship has taken place in a very significant way. Information Communication Technology (ICT) has paved the way for global connectivity (Wellman, et. al.,1996).

Virtual communication triggers social networks and distant relationships (Ravid, and Soroka (2004). Virtual communication has facilited the masses with communication opportunities at great distances for the quality of social life. New media technologies have reduces the distances among world borders (Wade, et. al., 2010). ICT has developed social network and caused rapid mobilization in contacts and social relationships. Communications technologies have increased the access to exchange the information and new dimension of social implications (Kenyona, et. al., 2002).

Significance of virtual communication in social context

Virtual communication has fostered motivation of knowledge sharing among the peoples. Social ties through electronic devices have integrated whole society as a global village (Chiu, et. al., 2006). Virtual communication has caused social movements as it has impact on the public opinion and common interest. Effective mobilization attempts to remain people connected and ICT is an instrumental for the virtual communication at personal and professional level (Diani, 2010).

People participation in Education, social and political information activities has become possible across the borders via virtual communication. Electronic devices shape the norms and attitudes through virtual communication. (Blanchard and Horan, 1998).

Many crucial and critical social actions are taking place with the help of computer aided communications in the developed and developing societies of the world. Collective mobilization occurs when educated masses prefer to un-limit the physical boundaries and initiate the virtual communication (Garretta, 2006).

\section{Hypothesis}

Purpose of the study is to assess the significance of the virtual communication among the people living in developing society of Pakistan. Response of the people was statistically analyzed through SPSS.

\section{Methods}

In order to accomplish the objective of the study, the data were collected through different sources. Primarily, observations and structure interviews were conducted across the people of different disciplines. 


\section{Questionnaire Design}

10 key questions were prepared to evaluate the required inform from the target group of the people, list of the questions is as below:
1. What is best mode of virtual communication for social use?
2. Virtual communication is preferred to use for?
3. People feel easy to communicate on distance through:
4. Virtual communication is in common use for which range?
5. Virtual communication mostly used for communication with?
6. Account(s) on Social Networking Sites:
7. Please state your tool to use social network:
8. How long have you been using social networking sites?
9. $\quad$ Please state your average hours of social networking site( s) use per day?
10. Reason(s) for Signing Up to these kinds of sites

\section{DATA COLLECTION}

100 people were randomly selected as the participants in this study, their response towards the questionnaire satisfied the objective of the research.

People of different ages, different qualification and different professions were focused to give neuter response. As frequency of age, education and profession is given in table below in entail the clear picture.

Figure 1 Statistics

\begin{tabular}{|l|r|r|r|}
\hline & \multicolumn{1}{|c|}{ Age } & Education & Profession \\
\hline $\mathrm{N} \quad$ Valid & 100 & 100 & 100 \\
Mean Missing & 6 & 6 & 6 \\
Std. Deviation & 33.47 & 4.13 & 2.80 \\
Variance & 10.015 & 1.195 & 1.295 \\
Minimum & 100.292 & 1.427 & 1.677 \\
Maximum & 22 & 1 & 1 \\
\hline
\end{tabular}

Table 1shows the statistics of participants in the research, statistics table of age of participants in which 33.47 is mean, 10.015 Std. Deviation, minimum age of participant is 22 and maximum age is 76 . While in the education column, total means is 4.13 , standard deviation is 1.195 , while variance is 1.427 , here minimum category of education is 1 which shows the $1^{\text {st }}$ level of education which was Matric while maximum level of education is 6 which is $\mathrm{PhD}$. The differences of age, education and profession of participants have submitted a general opinion of the masses in majority of the population of Pakistan.

Figure 3 Frequency of Education

\begin{tabular}{|ll|r|r|r|r|}
\hline & Frequency & Percent & Valid Percent & $\begin{array}{c}\text { Cumulative } \\
\text { Percent }\end{array}$ \\
\hline & Matric & 4 & 3.8 & 4.0 & 4.0 \\
& Intermediate & 6 & 5.7 & 6.0 & 10.0 \\
& Grdaduate & 11 & 10.4 & 11.0 & 21.0 \\
Valid & Masters & 43 & 40.6 & 43.0 & 64.0 \\
& PhD & 24 & 22.6 & 24.0 & 88.0 \\
& 6 & 12 & 11.3 & 12.0 & 100.0 \\
& Total & 100 & 94.3 & 100.0 & \\
Missing & System & 6 & 5.7 & & \\
Total & & 106 & 100.0 & & \\
\hline
\end{tabular}

Figure 3 shows the frequency of the participant according to their education, as there were 4 participants who had matric, there were 6 participants whose qualification was intermediate, and there were 11 participants who had graduation. 43 participants were having masters and there were 24 participants some of them were having $\mathrm{Ph} . \mathrm{D}$ degree and some of participants were doing PhD. 12 remaining were doing MS. 
Figure 4 Profession

\begin{tabular}{|rl|r|r|r|r|}
\hline & Frequency & Percent & Valid Percent & $\begin{array}{c}\text { Cumulative } \\
\text { Percent }\end{array}$ \\
\hline \multirow{3}{*}{ Valid } & Teacher & 12 & 11.3 & 12.0 & 12.0 \\
& Admin & 42 & 39.6 & 42.0 & 54.0 \\
& Banker & 17 & 16.0 & 17.0 & 71.0 \\
& Businessmen & 12 & 11.3 & 12.0 & 83.0 \\
& Student & 17 & 16.0 & 17.0 & 100.0 \\
& Total & 100 & 94.3 & 100.0 & \\
Total & & 106 & 100.0 & & \\
\hline
\end{tabular}

In order to reach the target study, people of different profession were chosen in which 12 were the teachers by profession, 42 were the admin, 17 were the bankers, 12 were businessmen, and 17 were the students. While against the frequency of participants, their percent entails their respective ratio.

\section{Data Analysis}

After collecting the required information from the participant, their response was analyzed through SPSS Statistics 20 and interpretation was made in MS Word.

\section{Result Of The Questionnaire Survey}

Considering the significance of virtual communication, it was important to study this issue in the Pakistan. In order to achieve these objectives a questionnaire survey was carried out in a city of Pakistan (i.e Hyderabad). The main participants of the survey were educated people. The study of virtual communication is based on the data collected from study of construction phase is based on the data collected from contractors. Total 75 Questionnaires were distributed to consultants and contactors. 58 companies responded to the questionnaire. Out of 58 respondents 33 were contractors and 25 were design consultants. The statistics of respondents, is depicted in Fig. 1.

\section{Collective Response}

Statistical analysis shows that participant were 100 in number and 10 key questions. Against each question, minimum response for all is 1 while maximum varies from question to question.

\section{Figure 5 Descriptive Statistics}

\begin{tabular}{|c|c|c|c|c|c|c|}
\hline & $\mathrm{N}$ & Minimum & Maximum & Mean & Std. Deviation & Variance \\
\hline $\begin{array}{l}\text { Virtual communication } \\
\text { mostly used for }\end{array}$ & 100 & 1 & 4 & 1.85 & .936 & .876 \\
\hline $\begin{array}{l}\text { Account(s) on Social } \\
\text { Networking Sites: }\end{array}$ & 100 & 1 & 3 & 1.97 & .870 & .757 \\
\hline $\begin{array}{l}\text { Please state your average } \\
\text { hours of social networking } \\
\text { site(s) use per day? }\end{array}$ & 100 & 1 & 4 & 2.02 & .910 & .828 \\
\hline $\begin{array}{l}\text { Reason(s) for Signing Up to } \\
\text { these kinds of sites: }\end{array}$ & 100 & 1 & 4 & 2.04 & .994 & .988 \\
\hline $\begin{array}{l}\text { People feel easy to } \\
\text { communicate on distance } \\
\text { through: }\end{array}$ & 100 & 1 & 4 & 2.27 & 1.062 & 1.128 \\
\hline $\begin{array}{l}\text { Account(s) on Social } \\
\text { Networking Sites: }\end{array}$ & 100 & 1 & 5 & 2.48 & 1.291 & 1.666 \\
\hline $\begin{array}{l}\text { People feel easy to } \\
\text { communicate on distance } \\
\text { through: }\end{array}$ & 100 & 1 & 5 & 2.58 & 1.707 & 2.913 \\
\hline $\begin{array}{l}\text { What is best mode of virtual } \\
\text { communication for social } \\
\text { use }\end{array}$ & 100 & 1 & 5 & 2.96 & 1.421 & 2.019 \\
\hline
\end{tabular}


Virtual communication is preferred to use for? How long have you been using social networking sites?

Valid N (listwise)

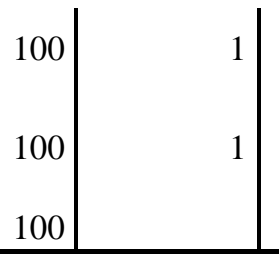

1.079

1.673
1.165

2.798

\section{Assessment Of Response On Individual Question}

Here one question have five multiple responses in $1^{\text {st }}$ column, $2^{\text {nd }}$ column shows the frequency of all participants in response of this question on multiple choice where most of people has chosen instant messaging and chat in $24.5 \%$ response individually that best mode of communication for the social use. While video conferencing is $2^{\text {nd }}$ large response with $23.6 \%$ and email is $4^{\text {th }}$ with $16 \%$ and forum is last and least with $5.7 \%$ response of all the participants.

Figure 6 What is best mode of virtual communication for social use

\begin{tabular}{|ll|r|r|r|r|}
\hline & Frequency & Percent & Valid Percent & $\begin{array}{c}\text { Cumulative } \\
\text { Percent }\end{array}$ \\
\hline \multirow{2}{*}{ E-Mail } & 17 & 16.0 & 17.0 & 17.0 \\
& Instant Messaging & 26 & 24.5 & 26.0 & 43.0 \\
Valid & Chat & 26 & 24.5 & 26.0 & 69.0 \\
& Forums & 6 & 5.7 & 6.0 & 75.0 \\
& Video Conferencing & 25 & 23.6 & 25.0 & 100.0 \\
Missing & Total & 100 & 94.3 & 100.0 & \\
Total & System & 6 & 5.7 & & \\
\hline
\end{tabular}

In response of $2^{\text {nd }}$ question, frequency of the participants varies as $12.3 \%$ people selected social purpose, $10.4 \%$ people selected political purpose, $33 \%$ people selected educational purpose and $3.8 \%$ people selected other reasons. Being a developed society, use of virtual communication in Pakistan is increasing and awareness is spreading through the mass media and person to person contact.

Figure 7 Virtual communications is preferred to use for?

\begin{tabular}{|ll|r|r|r|r|}
\hline & & Frequency & Percent & Valid Percent & $\begin{array}{c}\text { Cumulative } \\
\text { Percent }\end{array}$ \\
\hline \multirow{6}{*}{ Valid } & Social Purpose & 13 & 12.3 & 13.0 & 13.0 \\
& Political Purpose & 11 & 10.4 & 11.0 & 24.0 \\
& Educational Purpose & 35 & 33.0 & 35.0 & 59.0 \\
& Entertainment Purpose & 37 & 34.9 & 37.0 & 96.0 \\
& Other & 4 & 3.8 & 4.0 & 100.0 \\
Missing & Total & 100 & 94.3 & 100.0 & \\
Total & System & 6 & 5.7 & & \\
\hline
\end{tabular}

In response of $4^{\text {th }}$ question, frequency of participation in questionnaire shows their interest and attribution towards victual technology. As $43.4 \%$ people selected E-mail is easy way to communicate, $8.5 \%$ people selected instant messaging, $12.3 \%$ people selected chat, $4.7 \%$ people selected forum and second maximum priority was video conferencing with $25.5 \%$.

Figure 8 People feel easy to communicate on distance through:

\begin{tabular}{|ll|r|r|r|r|}
\hline & Frequency & Percent & Valid Percent & Cumulative \\
& & & & Percent \\
\hline \multirow{6}{*}{ Valid } & E-mail & 46 & 43.4 & 46.0 & 46.0 \\
& Instant Messaging & 9 & 8.5 & 9.0 & 55.0 \\
& Chat & 13 & 12.3 & 13.0 & 68.0 \\
& Forum & 5 & 4.7 & 5.0 & 73.0 \\
& Video Conferencng & 27 & 25.5 & 27.0 & 100.0 \\
Missing & Total & 100 & 94.3 & 100.0 & \\
Total & System & 6 & 5.7 & & \\
\hline
\end{tabular}


In response of $5^{\text {th }}$ question, participants selected different regional levels used for the virtual communication as $17.9 \%$ people mentioned that virtual communication is used at local level, 27.4\% people selected regional level, 23.6\% participants selected national level and 25.5\% participants selected international level. This frequent use of virtual communication is for the social interaction and to develop social bandage in easy, effective and at affordable level.

Figure 9 Regional levels of virtual communication

\begin{tabular}{|ll|r|r|r|r|}
\hline & & Frequency & Percent & Valid Percent & \multicolumn{2}{c|}{$\begin{array}{c}\text { Cumulative } \\
\text { Percent }\end{array}$} \\
\hline \multirow{6}{*}{ Valid } & Local level & 19 & 17.9 & 19.0 & 19.0 \\
& Regional Level & 29 & 27.4 & 29.0 & 48.0 \\
& National Level & 25 & 23.6 & 25.0 & 73.0 \\
& International Level & 27 & 25.5 & 27.0 & 100.0 \\
& Total & 100 & 94.3 & 100.0 & \\
Missing & System & 6 & 5.7 & & \\
Total & & 106 & 100.0 & & \\
\hline
\end{tabular}

In response of $6^{\text {th }}$ question, frequency of participation shows vital interest of people in virtual communication. $41.5 \%$ participants selected the use of virtual communication for the family, while $33 \%$ participant selected the use of virtual communication for the friends, $12.3 \%$ for the colleagues, and $7.5 \%$ for the officials.

Figure 10 Virtual communication mostly used for communication with?

\begin{tabular}{|c|c|c|c|c|c|}
\hline & & Frequency & Percent & Valid Percent & $\begin{array}{c}\text { Cumulative } \\
\text { Percent }\end{array}$ \\
\hline \multirow{5}{*}{ Valid } & Family & 44 & 41.5 & 44.0 & 44.0 \\
\hline & Friends & 35 & 33.0 & 35.0 & 79.0 \\
\hline & Colleagues & 13 & 12.3 & 13.0 & 92.0 \\
\hline & Officials & 8 & 7.5 & 8.0 & 100.0 \\
\hline & Total & 100 & 94.3 & 100.0 & \\
\hline \multirow{2}{*}{$\begin{array}{l}\text { Missing } \\
\text { Total }\end{array}$} & System & 6 & 5.7 & & \\
\hline & & 106 & 100.0 & & \\
\hline
\end{tabular}

In response of $7^{\text {th }}$ question, selection of social networking sites varied according to their interest, $34 \%$ participants selected Facebook for the social communication, 10.4\% selected MySpace, 23.6\% participants selected Linkedin, $23.6 \%$ participants selected twitter for the social interaction through virtual communication.

Figure 11 Account(s) on Social Networking Sites:

\begin{tabular}{|ll|r|r|r|r|}
\hline & Frequency & Percent & Valid Percent & \multicolumn{2}{c|}{$\begin{array}{c}\text { Cumulative } \\
\text { Percent }\end{array}$} \\
\hline \multirow{6}{*}{ Valid } & Facebook & 36 & 34.0 & 36.0 & 36.0 \\
& MySpace & 11 & 10.4 & 11.0 & 47.0 \\
& Linkedin & 25 & 23.6 & 25.0 & 72.0 \\
& Twitter & 25 & 23.6 & 25.0 & 97.0 \\
& Other & 3 & 2.8 & 3.0 & 100.0 \\
Missing & Total & 100 & 94.3 & 100.0 & \\
Total & System & 6 & 5.7 & & \\
\hline
\end{tabular}

In response of $8^{\text {th }}$ question, $36.8 \%$ participants selected to use $\mathrm{PC}$ for the virtual communication, $23.6 \%$ participants preferred to select Laptop for the social interaction, $34 \%$ people entailed their interest to use Smartphone for the social communication.

Figure 12 Tool of the Virtual communication

\begin{tabular}{|ll|r|r|r|r|}
\hline & Frequency & Percent & Valid Percent & $\begin{array}{c}\text { Cumulative } \\
\text { Percent }\end{array}$ \\
\hline & PC & 39 & 36.8 & 39.0 & 39.0 \\
Valid & Laptop & 25 & 23.6 & 25.0 & 64.0 \\
& Smartphone & 36 & 34.0 & 36.0 & 100.0 \\
& Total & 100 & 94.3 & 100.0 & \\
Missing & System & 6 & 5.7 & & \\
Total & 106 & 100.0 & & \\
\hline
\end{tabular}


In response of $9^{\text {th }}$ question, participants mentioned different time period to use the social networking sites for the virtual communication, $7.5 \%$ people selected to use the social networking since less than a month, $5.7 \%$ selected 1-6 month, $6.6 \%$ selected $1-2$ years, $10.4 \%$ participants selected $2-3$ years, and $57.5 \%$ showed that they have been using social networking since more than 3 years.

Figure 13 How long have you been using social networking sites?

\begin{tabular}{|ll|r|r|r|r|}
\hline & Frequency & Percent & Valid Percent & $\begin{array}{c}\text { Cumulative } \\
\text { Percent }\end{array}$ \\
\hline \multirow{6}{*}{ Less than a month } & 8 & 7.5 & 8.0 & 8.0 \\
1-6 months & 6 & 5.7 & 6.0 & 14.0 \\
Valid & 7 & 6.6 & 7.0 & 21.0 \\
& 1-2 yenths to a year & 7 & 6.6 & 7.0 & 28.0 \\
& 2-3 years & 11 & 10.4 & 11.0 & 39.0 \\
& More than 3 years & 61 & 57.5 & 61.0 & 100.0 \\
& Total & 100 & 94.3 & 100.0 & \\
Missing & System & 6 & 5.7 & & \\
Total & & 106 & 100.0 & & \\
\hline
\end{tabular}

In response of $9^{\text {th }}$ question, participants showed various time ranges for the use of social networking sites as $30.3 \%$ participants mentioned $1-2$ hours, $39.6 \%$ participants selected 3-4 hours, $17 \%$ selected 5-6 hours, and $7.5 \%$ participants selected $7-8$ hours use of social networking sites for the virtual communication.

Figure 14 Please state your average hours of social networking site(s) use per day?

\begin{tabular}{|rl|r|r|r|r|}
\hline & Frequency & Percent & Valid Percent & \multicolumn{2}{c|}{$\begin{array}{c}\text { Cumulative } \\
\text { Percent }\end{array}$} \\
\hline & 1-2 hours & 32 & 30.2 & 32.0 & 32.0 \\
Valid & 3-4 hours & 42 & 39.6 & 42.0 & 74.0 \\
& 5-6 hours & 18 & 17.0 & 18.0 & 92.0 \\
& 7-8 hours & 8 & 7.5 & 8.0 & 100.0 \\
Missing & Total & 100 & 94.3 & 100.0 & \\
Total & System & 6 & 5.7 & & \\
\hline
\end{tabular}

In response of $10^{\text {th }}$ question, participants preferred different options/reasons for the sign up of the social networking. As 35.8\% participants selected the use of virtual communication for Reaching out your far distant relatives and friends. 27.4\% participants selected the use of virtual communication for current trend, $22.6 \%$ participants selected to use social networking to Acquire new Friends or Gain new Acquaintances and 8.5\% participants selected to be able to use the applications or special features provide by these sites.

Figure 15 Reason(s) for Signing Up to these kinds of sites:

\begin{tabular}{|rl|r|r|r|r|}
\hline & Frequency & Percent & Valid Percent & \multicolumn{1}{c|}{$\begin{array}{c}\text { Cumulative } \\
\text { Percent }\end{array}$} \\
\hline & $\begin{array}{l}\text { Reaching out your far } \\
\text { distant relatives and } \\
\text { friends }\end{array}$ & 38 & 35.8 & 38.0 & 38.0 \\
& 29 & 27.4 & 29.0 & 67.0 \\
Current Trend & 24 & 22.6 & 24.0 & 91.0 \\
Acquire new Friends or & & & & \\
Valid & & & \\
& $\begin{array}{l}\text { Gain new Acquaintances } \\
\text { To be able to use the } \\
\text { applications or special } \\
\text { features provide by these } \\
\text { sites. }\end{array}$ & 9 & 8.5 & 9.0 & 100.0 \\
& & & & \\
Total & 100 & 94.3 & 100.0 & \\
Missing & System & 106 & 100.0 & & \\
Total & & & & \\
\hline
\end{tabular}




\section{Conclusion}

This is an optimistic approach of the society to get integrated through virtual communication across the borders. Information Communication Technology (ICT) is a tool of social integration. Besides, rapid acquisition and application of technology, complete use of technology and its valuable significance should be extended to the illiterate or low educated people of the society in order to avail complete benefits of the ICT. Virtual communication is rapidly increasing and popular trend of communication in the developed and developing societies of the world. Simultaneously, it is had influenced the society of Pakistan by its new dimensions and interesting aspects. Educational and social cause has increased the worth of technology at individual and collective levels (Tunio, et. al, 2012).

\section{LIMITATIONS}

1. Factor of gender was not counted as females were not included in research

2. Size of sample is a small to represent whole population due to limited time

3. Demographic study could produce more recommended result

4. Funds were not available for extensive study

\section{Acknowledgement}

Authors are cordially thankful to the participants who hardly managed to give time from their busy schedule for this research.

\section{References}

[1]. B. Wellman, J. Salaff, D. Dimitrova, L. Garton, M. Gulia, C. Haythornthwaite, Computer Network as a social networks: collaborative work, telenetwork, and virtual community. Annual Review of Sociology. Vol. 22, 1996, pp. 213-238

[2]. G. Ravid, V. Soroka, De-lurking in virtual communities: a social communication network approach to measuring the effects of social and cultural capital. System Sciences. Proceedings of the 37th Annual Hawaii International Conference, 2004.

[3]. B. Wade, D. Carson, T. Lea, Virtual galleries: First insights into the effect of the introduction of new media technologies, in art galleries, on economic and social wellbeing in urban and remote communities of the Northern Territory of Australia. Virtual Systems and Multimedia (VSMM), 2010 16th International Conference. 20-23 Oct. 2010.

[4]. S. Kenyona, G. Lyonsa, J. Raffertyb, Transport and social exclusion: investigating the possibility of promoting inclusion through virtual mobility. Journal of Transport Geography. Volume 10, Issue 3, 2002, Pages 207-219.

[5]. C. Chiu, M. H. Hsu, E.T.G. Wangc, Understanding knowledge sharing in virtual communities: An integration of social capital and social cognitive theories. Decision Support Systems. Volume 42, Issue 3, 2006, P. 1872-1888.

[6]. M. Diani, Social Movement Networks Virtual and Real. Information, Communication \& Society. Volume 3, Issue 3, 2010.

[7]. Blanchard, T. Horan, Virtual Communities and Social Capital. Social Science Computer Review October 1998 vol. 16 no. 3 , 1998 , 293-307.

[8]. R. K. Garretta, Protest in an Information Society: a review of literature on social movements and new ICTs. Information, Communication \& Society. Volume 9, Issue 2, 2006.

[9]. M. N. Tunio, P. I. S. Rashdi, Q. M. M. Abro, the influence of ICT on Public secondary schools in Pakistan. A case study of Tandojam Vs Hyderabad. 1st Asian Business Research Conference proceedings, ISSN 2227-7935, 2012, PP.134-143. 